\title{
Lack of Association between Folate-Receptor Autoantibodies and Neural-Tube Defects
}

\author{
Anne M. Molloy, Ph.D., Edward V. Quadros, Ph.D., Jeffrey M. Sequeira, M.S., \\ James F. Troendle, Ph.D., John M. Scott, Sc.D., Peadar N. Kirke, F.F.P.H.M.I., \\ and James L. Mills, M.D.
}

ABSTRACT

From the Schools of Medicine (A.M.M.) and Biochemistry and Immunology (A.M.M., J.M. Scott), Trinity College; and the Child Health Epidemiology Unit, Health Research Board (P.N.K.) - both in Dublin; the Departments of Medicine and Cell Biology, State University of New York-Downstate Medical Center, Brooklyn (E.V.Q., J.M. Sequeira); and the Division of Epidemiology, Statistics and Prevention Research, Eunice Kennedy Shriver National Institute of Child Health and Human Development, National Institutes of Health, Bethesda, MD (J.F.T., J.L.M.). Address reprint requests to $\mathrm{Dr}$. Molloy at the School of Biochemistry and Immunology, Trinity College Dublin, Dublin 2, Ireland, or at amolloy@tcd.ie.

Drs. Molloy and Quadros contributed equally to this article.

N Engl J Med 2009;361:152-60.

Copyright @ 2009 Massachusetts Medical Society.

\section{BACKGROUND}

A previous report described the presence of autoantibodies against folate receptors in $75 \%$ of serum samples from women with a history of pregnancy complicated by a neural-tube defect, as compared with $10 \%$ of controls. We sought to confirm this finding in an Irish population, which traditionally has had a high prevalence of neuraltube defects.

\section{METHODS}

We performed two studies. Study 1 consisted of analysis of stored frozen blood samples collected from 1993 through 1994 from 103 mothers with a history of pregnancy complicated by a neural-tube defect (case mothers), 103 mothers with a history of pregnancy but no complication by a neural-tube defect (matched with regard to number of pregnancies and sampling dates), 58 women who had never been pregnant, and 36 men. Study 2, conducted to confirm that the storage of samples did not influence the folate-receptor autoantibodies, included fresh samples from 37 case mothers, 22 control mothers, 10 women who had never been pregnant, and 9 men. All samples were assayed for blocking and binding autoantibodies against folate receptors.

\section{RESULTS}

In Study 1, blocking autoantibodies were found in $17 \%$ of case mothers, as compared with $13 \%$ of control mothers (odds ratio, 1.54; 95\% confidence interval [CI], 0.70 to 3.39 ), and binding autoantibodies in $29 \%$, as compared with $32 \%$, respectively (odds ratio, $0.82 ; 95 \%$ CI, 0.44 to 1.50 ). Study 2 showed similar results, indicating that sample degradation was unlikely.

\section{CONCLUSIONS}

The presence and titer of maternal folate-receptor autoantibodies were not significantly associated with a neural-tube defect-affected pregnancy in this Irish population. 
LTHOUGH PERICONCEPTIONAL FOLIC acid supplementation can prevent neuraltube defects, the underlying mechanism is not well understood. ${ }^{1}$ In 2004 , a pilot study published in the Journal ${ }^{2}$ showed that serum from 9 of 12 women (75\%) with a history of a neural-tube defect-affected pregnancy (case mothers) contained autoantibodies against folate receptors, whereas autoantibodies were detected in samples from only 2 of 20 controls (10\%). The hypothesis that embryonic uptake of folate might be impaired by circulating maternal folate-receptor autoantibodies presents a biologically plausible mechanism for the pathogenesis of folate-responsive neuraltube defects. Although the authors called for further studies to confirm their findings, data are limited. ${ }^{3}$

One factor that may contribute to the limited study of this question is the technical complexity of the assays in the original report, which involved the use of folate receptors purified from human placental tissue. Moreover, modifications were made to the assay in follow-up work from the same laboratory. These included developing a specific assay to determine the presence of autoantibodies that block the binding of folic acid to folate receptors ${ }^{4,5}$ and using folate receptors purified from cow's milk in an enzyme-linked immunosorbent assay (ELISA) to identify binding autoantibodies. ${ }^{6}$ Using a similar ELISA technique, a recent study $^{3}$ showed higher mean autoantibody titers in serum samples obtained midgestation from women whose pregnancy was affected by a neural-tube defect than in those from pregnant controls, but the prevalence of autoantibodies in the two groups was not reported.

We performed two studies involving case mothers and control mothers from Ireland, a region that traditionally has a high prevalence of neuraltube defects, ${ }^{7}$ to assess associations between a history of a pregnancy complicated by a neuraltube defect and the presence and titer of folatereceptor autoantibodies, measured in the laboratory where the original pilot study was conducted.

\section{METHODS}

\section{STUDY SUBJECTS}

Case and control samples were collected in two separate studies. Ethical approval was obtained for both studies from the Research Ethics Committee of the Irish Health Research Board. All participants provided written informed consent.
In Study 1, blood specimens were collected from 1993 through 1994, with the assistance of the Irish Association for Spina Bifida and Hydrocephalus, as part of a campaign to recruit mothers and fathers of families affected by neural-tube defects and appropriate controls throughout the Republic of Ireland. ${ }^{8,9}$ Controls with no family history of birth defects were recruited from among friends of case families, university and hospital staff, and outpatients attending orthopedic clinics. In all, 123 case mothers and 620 controls were recruited, including men and women who had never been pregnant.

All participants completed comprehensive questionnaires detailing their family history of birth defects and their pregnancy history. The current intake of folic acid and multivitamin supplements was recorded. Blood specimens were collected in tubes containing potassium EDTA, and plasma was stored in aliquots, at temperatures below $-40^{\circ} \mathrm{C}$.

All participants were eligible for the current study. Sufficient plasma was available from 103 case mothers, and each was matched with a control mother, on the basis of the number of pregnancies and the fewest days since the case mother's sample was obtained (mean difference [ $\pm \mathrm{SD}]$, 42+96). Women who had never been pregnant and men were randomly selected from among the controls, with exclusion of those with insufficient plasma.

The final study set of 300 samples consisted of those from 103 case mothers, 103 matched-control mothers, 58 women who had never been pregnant, and 36 men. Case and control blood samples were coded, identifying information was removed, and all 300 blood specimens were sent to the analysis laboratory. Technicians performing the analyses were unaware of the case or control status.

Study 1 was designed to test whether the presence of folate-receptor autoantibodies was associated with a maternal risk of having a pregnancy affected by a neural-tube defect. However, because samples were not fresh, as they were in the pilot study, and because plasma was used instead of serum (which was used in the pilot study), we performed a follow-up study in 2007 (Study 2) to rule out sample degradation or an inappropriate sample matrix as explanations for the negative results in Study 1.

For Study 2, serum samples were collected on the same day from case mothers and from nonpregnant volunteers with no family history of birth 
defects. The current intake of folic acid and multivitamin supplements was recorded. In total, blood specimens were obtained from 37 case mothers, 22 control mothers, 10 women who had never been pregnant, and 9 men. Case and control samples were coded, and identifying information was removed; samples were sent, within 48 hours after collection, to the analysis laboratory, after reserving an aliquot for folate measurement by means of microbiologic assay. ${ }^{10}$

\section{ANALYTICAL METHODS}

Folate receptors from cow's milk and human placental tissue were solubilized in $0.01 \mathrm{M}$ sodium phosphate buffer ( $\mathrm{pH}$ 7.4) containing $1 \%$ Triton $\mathrm{X}-100$ and were purified with the use of affinity chromatography on a folic acid-Sepharose $4 \mathrm{~B}$ matrix. The purity of receptors was checked by means of sodium dodecyl sulfate-polyacrylamide-gel electrophoresis and binding to $\left[{ }^{3} \mathrm{H}\right]$ folic acid (specific activity, 31 Ci per millimole; Moravek), as described previously. ${ }^{4}$ Plasma or serum samples from case mothers and controls were acidified to $\mathrm{pH} 3.0$ with $0.1 \mathrm{M}$ glycine buffer, and folate was removed through adsorption to dextran-coated charcoal. The folate-free supernatant was neutralized with $1 \mathrm{M}$ dibasic sodium phosphate and used in assays to determine the presence of folate-receptor autoantibodies.

The assay for autoantibodies that blocked the binding of folic acid to folate receptors was carried out as described previously. ${ }^{4,5}$ Briefly, $30 \mu \mathrm{l}$ of folate-free plasma or serum supernatant was incubated overnight at $4^{\circ} \mathrm{C}$ with $0.01 \mathrm{M}$ sodium phosphate buffer ( $\mathrm{pH} 7.4$ ) containing $0.5 \%$ Triton $\mathrm{X}-100$ and 0.18 pmol of purified receptor, in a volume of $\left.500 \mu \mathrm{l} .{ }^{3} \mathrm{H}\right]$ folic acid was added and the mixture was incubated for 30 minutes at room temperature. Free $\left[{ }^{3} \mathrm{H}\right]$ folic acid was removed by adsorption to charcoal, and radioactivity in the supernatant containing receptor-bound $[\mathrm{B} \mathrm{H}]$ folic acid was measured. The autoantibody titer was calculated from the decrease in radioactivity, relative to that in a parallel reaction without serum extract. These "blocking autoantibodies" results are expressed as picomoles of folate receptor blocked per milliliter of serum or plasma.

An ELISA was used to determine the presence of IgG bound to epitopes on purified folate receptors. ${ }^{6}$ In this assay, purified folate receptors from cow's milk or human placental tissue were immobilized in 96-well plates. Unbound sites were blocked with rabbit serum. Aliquots of folate-free plasma or serum supernatants were added and incubated overnight at $4^{\circ} \mathrm{C}$. The presence of autoantibodies was detected through complexing with biotin-conjugated goat antibodies against human IgG, followed by the addition of avidin-biotin-peroxidase complex and colorimetric reaction with tetramethylbenzidine. The autoantibody titer was quantified with the use of a standard curve for known amounts of human IgG captured in a protein A-coated ELISA plate and colorimetric reaction with tetramethylbenzidine. Nonspecific binding was determined in laboratory control samples, and a value of 2 SD above the mean was considered to represent nonspecific binding. This value was subtracted from the values for all study samples. These data for "binding autoantibodies" are expressed as picomoles of IgG per milliliter of serum or plasma.

Assays for autoantibodies used cow's-milk folate receptors as the antigen in Study 1 and human placental folate receptors as the antigen in Study 2. As demonstrated previously, ${ }^{6}$ there was a high degree of antibody cross-reactivity between human placental folate receptors and cow's-milk folate receptors, with a correlation coefficient (r) of 0.82 in the ELISA. To validate the new ELISA, available serum samples from five controls that were negative for autoantibodies and seven index subjects that were positive for autoantibodies from the original study ${ }^{2}$ were evaluated. The new ELISA showed that all samples from the original index subjects remained positive and all samples from the controls remained negative. The prevalence of autoantibodies in blood specimens from 111 healthy U.S. adults under 50 years of age was $12 \%$ on the basis of this assay, a rate similar to that reported in the original study.

\section{STATISTICAL ANALYSIS}

We used logistic-regression models to analyze the data in Study 1 with case mother versus matchedcontrol mother as the outcome variable and presence or titer of blocking antibody, presence or titer of binding antibody, and age as explanatory variables. Subjects without autoantibodies were assigned an antibody titer of 0 and were included in the model to analyze dose effects. We used Fisher's exact test and the Kruskal-Wallis test to assess differences in autoantibody frequencies and titers, respectively, among the matched-control mothers, the women who had never been preg- 


\begin{tabular}{|c|c|c|c|c|}
\hline Characteristic & Case Mothers & Control Mothers & $\begin{array}{l}\text { Women Who Had } \\
\text { Never Been } \\
\text { Pregnant }\end{array}$ & Men \\
\hline \multicolumn{5}{|l|}{ Study 1} \\
\hline No. of subjects & 103 & 103 & 58 & 36 \\
\hline \multicolumn{5}{|l|}{ Age at study $-y r$} \\
\hline Median & 44 & 43 & 32 & 39 \\
\hline Range & $21-67$ & $25-73$ & $20-75$ & $21-65$ \\
\hline $\begin{array}{l}\text { Years since birth affected by neural-tube defect - } \\
\text { median (range) }\end{array}$ & $13(0-33)$ & & & \\
\hline No. of pregnancies - median (range) & $4(1-14)$ & $4(1-16)$ & & \\
\hline \multicolumn{5}{|l|}{ Pregnancies affected by neural-tube defect — no. (\%) } \\
\hline 1 & $93(90)$ & & & \\
\hline 2 & $9(9)$ & & & \\
\hline 3 & $1(1)$ & & & \\
\hline No. of live births - median (range) & $4(1-11)$ & $4(1-13)$ & & \\
\hline No. of miscarriages - median (range) & $0(0-8)$ & $0(0-4)$ & & \\
\hline $\begin{array}{l}\text { Use of folic acid supplements at time of sampling } \\
\qquad \text { - no. (\%) }\end{array}$ & $9(9)$ & 0 & 0 & 0 \\
\hline \multicolumn{5}{|l|}{ Study 2} \\
\hline No. of subjects & 37 & 22 & 10 & 9 \\
\hline \multicolumn{5}{|l|}{ Age at study $-y r$} \\
\hline Median & 49 & 44 & 30 & 54 \\
\hline Range & $26-64$ & $20-58$ & $24-48$ & $37-58$ \\
\hline $\begin{array}{l}\text { Years since birth affected by neural-tube defect - } \\
\text { median (range) }\end{array}$ & $18(2-33)$ & & & \\
\hline No. of pregnancies - median (range) & $3(1-7)$ & $2(1-7)$ & & \\
\hline \multicolumn{5}{|l|}{$\begin{array}{l}\text { Pregnancies affected by neural-tube defect - } \\
\text { no. (\%) }\end{array}$} \\
\hline 1 & $32(86)$ & & & \\
\hline 2 & $5(14)$ & & & \\
\hline No. of live births - median (range) & $3(1-6)$ & $2(0-4)$ & & \\
\hline $\begin{array}{l}\text { Use of folic acid supplements at time of sampling - } \\
\text { no. (\%) }\end{array}$ & $4(11)$ & $2(9)$ & $3(30)$ & 0 \\
\hline
\end{tabular}

nant, and the men. To determine whether the Study 1 autoantibody data were reliable, we compared the autoantibody frequencies and titers between Study 1 and Study 2 within each subject group, using Fisher's exact test and the Wilcoxon rank-sum test, respectively. We used analysis of variance followed by Tukey's Studentized range test to examine differences in age across subject groups. We used Spearman rank-correlation coefficients to examine associations between continuous variables. All analyses were done with the use of SAS software, version 9. P values of less than 0.05 were considered to indicate statistical significance and were not adjusted for multiple analyses.

\section{RESULTS}

Table 1 shows the baseline characteristics of the study subjects. Women who had never been pregnant were younger than the case mothers and the other controls $(\mathrm{P}<0.001)$. The pregnancy affected by a neural-tube defect had occurred within the previous 5 years in 23 case mothers (17 of 103 


\begin{tabular}{|c|c|c|c|c|c|}
\hline \multirow[t]{2}{*}{ Study } & \multirow[t]{3}{*}{ Case Mothers } & \multirow{2}{*}{\multicolumn{2}{|c|}{$\begin{array}{cc} & \begin{array}{c}\text { Women Who Had } \\
\text { Never Been } \\
\text { Control Mothers } \quad \text { Pregnant }\end{array}\end{array}$}} & \multirow[t]{3}{*}{ Men } & \multirow[t]{3}{*}{ P Value* } \\
\hline & & & & & \\
\hline \multicolumn{3}{|l|}{$\begin{array}{l}\text { Folate-receptor-blocking } \\
\text { autoantibodies }\end{array}$} & & & \\
\hline Study 1 & 18/103 (17) & $13 / 103(13)$ & $14 / 58(24)$ & $12 / 36(33)$ & 0.02 \\
\hline Study 2 & $6 / 37(16)$ & $2 / 22(9)$ & $2 / 10(20)$ & $2 / 9(22)$ & \\
\hline P value, Study 1 vs. Study 2 & 1.0 & 1.0 & 1.0 & 0.70 & \\
\hline \multicolumn{6}{|l|}{$\begin{array}{l}\text { Folate-receptor-binding } \\
\text { autoantibodies }\end{array}$} \\
\hline Study 1 & $30 / 103(29)$ & $33 / 103(32)$ & $16 / 58(28)$ & $8 / 36(22)$ & 0.54 \\
\hline Study 2 & $12 / 37(32)$ & $9 / 22(41)$ & $3 / 10(30)$ & $2 / 9(22)$ & \\
\hline P value, Study 1 vs. Study 2 & 0.83 & 0.46 & 1.0 & 1.0 & \\
\hline
\end{tabular}

* The $\mathrm{P}$ values are for the comparison among the three control groups. The P value for the case-control comparison was not significant.

[17\%] in Study 1 and 6 of 37 [16\%] in Study 2). Table 2 shows the numbers of case mothers and controls whose serum samples were positive for autoantibodies in Study 1 and Study 2. A total of 117 subjects (39\%) in Study 1 and 33 (42\%) in Study 2 had samples positive for either type of folate-receptor autoantibody; $9 \%$ and 6\%, respectively, were positive for both types. Autoantibody titers did not correlate significantly with the number of pregnancies $(r=-0.08$ for blocking autoantibodies and $r=0.02$ for binding autoantibodies) or with age at the time of sampling $(r=-0.07$ for blocking autoantibodies and $\mathrm{r}=-0.08$ for binding autoantibodies). Neither current supplement intake (in Study 1 or Study 2) nor serum folate level (in Study 2) was significantly associated with the presence of autoantibodies (data not shown).

In Study 1, according to a logistic-regression analysis, neither the presence nor the titer of folate-receptor autoantibodies was significantly associated with a history of pregnancy complicated by a neural-tube defect (Table 3). Results were similar in an analysis that excluded women reporting the use of folic acid or multivitamin supplements (data not shown). Among the three Study 1 control groups, there were no significant differences in binding autoantibody frequency $(\mathrm{P}=0.54)$, but significant differences were observed in blocking autoantibody frequency $(\mathrm{P}=0.02)$, with men having the highest frequency and control mothers having the lowest (Table 2). In the subgroup of subjects with detectable autoantibody titers, titers were not significantly different among the control groups $(\mathrm{P}=0.36$ and $\mathrm{P}=0.74$ for blocking and binding, respectively) (Fig. 1).

To establish that the data from Study 1 were reliable, we compared the frequency of the presence of autoantibodies and their titers between case mothers in Study 1 and Study 2 and between control groups in Study 1 and Study 2 (Table 2 and Fig. 1); no significant differences were found. When we considered only subjects with detectable autoantibody titers, the blocking-antibody levels were lower in Study 2 than in Study 1 among case mothers, control mothers, and women who had never been pregnant ( $\mathrm{P}=0.02$ for all three comparisons), contrary to what might be expected if there were sample degradation. In addition, we performed a logistic-regression analysis of autoantibody frequency for case mothers as compared with control mothers, in Study 2, with the presence or absence of both types of autoantibody, age, and number of pregnancies as explanatory variables - and found no significant association between the presence of autoantibodies and case status.

In the previously reported pilot study, ${ }^{2}$ the median time elapsed since the birth of the baby with a neural-tube defect was 6 years, whereas it was 13 years in Study 1 . To address the possibility that autoantibodies present at the time of the pregnancy affected by the neural-tube defect had disappeared from plasma over time, we fitted the model of blocking and binding autoantibodies 


\begin{tabular}{|c|c|c|c|c|c|c|}
\hline Effect & $\begin{array}{l}\text { Case Mothers } \\
\text { with Autoantibodies } \\
\text { no./to }\end{array}$ & $\begin{array}{l}\text { Control Mothers } \\
\text { with Autoantibodies } \\
\text { tal no. }\end{array}$ & $\begin{array}{l}\text { Odds Ratio for Presence } \\
\text { of Autoantibody'i } \\
(95 \% \mathrm{Cl})\end{array}$ & P Value & $\begin{array}{l}\text { Odds Ratio for 1-pmol } \\
\text { Increase of Receptor } \\
\text { or IgG Blocked } \%\end{array}$ & P Value \\
\hline Blocking & $18 / 103$ & $13 / 103$ & $1.54(0.70-3.39)$ & 0.29 & $1.70(0.27-10.74)$ & 0.57 \\
\hline Binding & $30 / 103$ & $33 / 103$ & $0.82(0.44-1.50)$ & 0.51 & $1.01(0.95-1.07)$ & 0.76 \\
\hline $\begin{array}{l}\text { Age at time } \\
\text { of sampling }\end{array}$ & & & $1.00(0.97-1.03)$ & 0.89 & $1.00(0.97-1.03)$ & 0.92 \\
\hline
\end{tabular}

* In both analyses, folate-receptor-blocking autoantibody, folate-receptor-binding autoantibody, and maternal age were used as independent explanatory variables.

$\dagger$ In this analysis, the odds ratio was for the presence versus the absence of autoantibodies.

In this analysis, the odds ratio was for an increase of 1 pmol of folate receptor blocked (for blocking autoantibodies), or of IgG (for binding autoantibodies), per milliliter of serum. Mothers without folate-receptor autoantibodies were assigned a titer of 0.

with data from all the case mothers and included a term for the number of years since the birth of the baby with a neural-tube defect. There was no significant association between the time elapsed since the defect-affected pregnancy and the presence of either blocking autoantibodies (odds ratio, $0.97 ; 95 \%$ confidence interval [CI], 0.91 to 1.03 ) or binding autoantibodies (odds ratio, 0.99; 95\% CI, 0.94 to 1.03 ).

\section{DISCUSSION}

We found no significant association between the presence or titer of folate-receptor autoantibodies and a history of pregnancy affected by neural-tube defect in two case-control studies. Our sample size of 103 cases and 103 matched-control mothers in Study 1 was approximately eight times the size of the pilot-study population. ${ }^{2}$ Our Study 2 was also larger than the pilot study and confirmed the absence of a significant association with the use of fresh samples.

The pilot study used human placental folate receptors and the assay detected IgG antibodies that bound to epitopes on any part of the folate receptor. ${ }^{2}$ Although our inclusion criteria were similar to those in the earlier study, our study was carried out with the use of stored samples, and our methods differed in that separate assays were designed to measure autoantibodies that specifically blocked the folic acid-binding site and to measure autoantibodies that bound to other receptor epitopes. ${ }^{4,5}$ Furthermore, purified cow's-milk folate receptors were used as the antigen. ${ }^{6}$ These changes were validated in earlier reports ${ }^{4-6}$; in the present report, we demonstrated, using a subgroup of samples from the original study, that the new ELISA yielded consistent results. The results of our Study 2 confirm a high level of agreement between the results from cow's-milk folate receptors and human placental folate receptors and from stored and fresh samples and show that sample degradation during storage was unlikely. It is likely that folate intake was higher and health care was improved among the women who were sampled in Study 2 as compared with those in Study 1; however, this would not be expected to affect the usefulness of the second group as a validation set, because neither folic acid supplementation nor blood folate level was significantly related to presence or titer of autoantibodies. Results of additional analyses indicated that neither the number of pregnancies, the time elapsed since the pregnancy affected by a neural-tube defect, nor maternal age related significantly to the presence of autoantibodies; thus, we consider these factors unlikely to explain the negative results in the present studies as compared with the original one.

The $95 \%$ confidence intervals around the calculated odds ratio for the presence of blocking autoantibodies ( 0.70 to 3.39 ) and binding autoantibodies (0.44 to 1.50 ) do not rule out the possibility of a modest association between these antibodies and a neural-tube defect. However, the results are inconsistent with the increase by a factor of 27 in the risk of a neural-tube defect associated with the presence of binding autoantibodies in the pilot study.

The prevalence of binding autoantibodies in our control samples was about three times that seen in U.S. laboratory controls (12\%) and that in the published pilot study. ${ }^{2}$ However, in a small study 


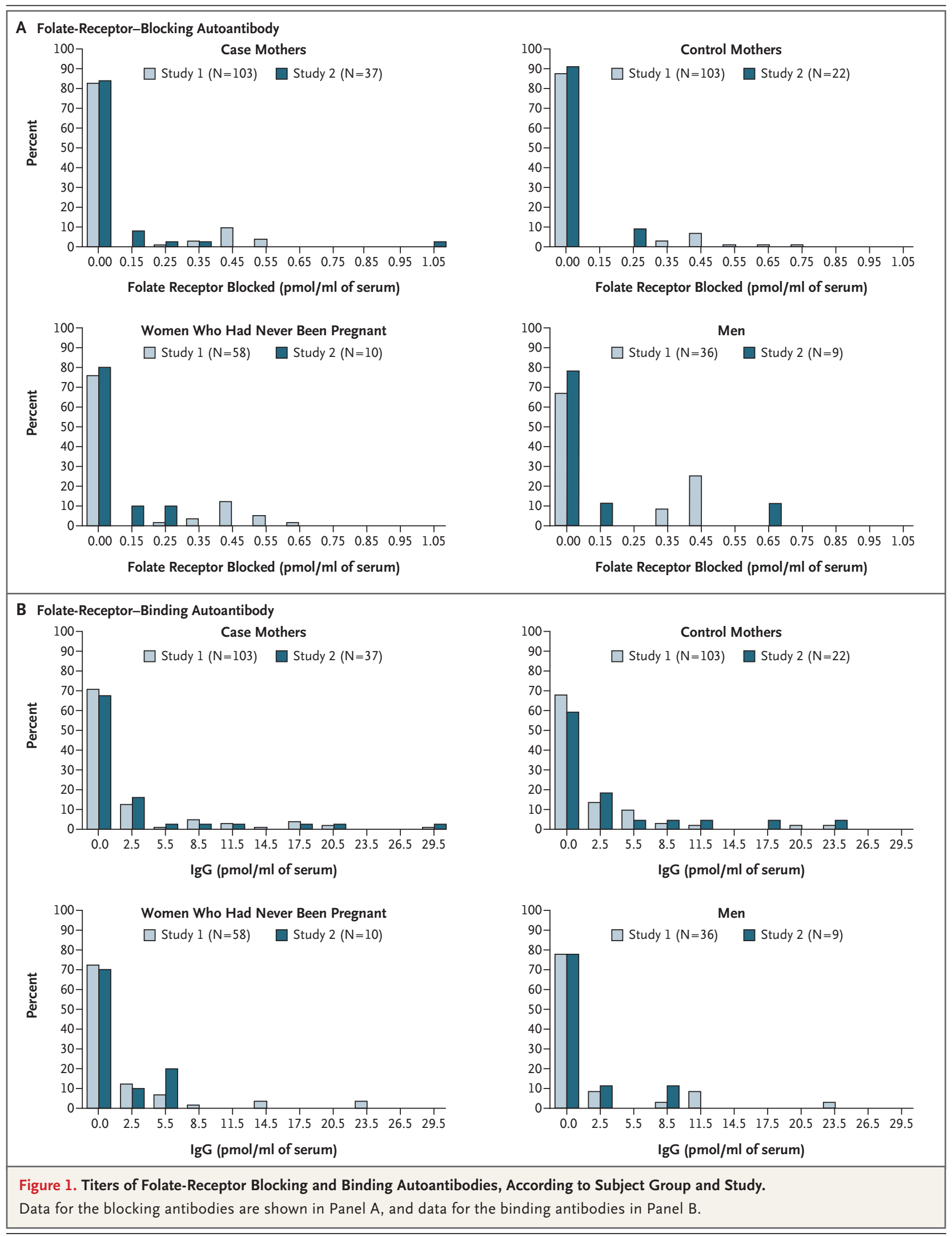


of patients in the Netherlands who had orofacial cleft, folate-receptor autoantibodies were observed in $30 \%$ of control mothers. ${ }^{11}$ In a study of cerebral folate deficiency syndrome in children, ${ }^{4}$ none of 28 matched-control subjects and 41 controls with neurologic disease had folate-receptor autoantibodies. A study of subfertility in Spanish women identified folate-receptor-blocking autoantibodies in only $4 \%$ of controls, whereas $29 \%$ of case patients were positive for the autoantibodies. ${ }^{12}$ These variations suggest that the prevalence of these autoantibodies might vary widely across populations; more data are needed to determine possible effects of genetic factors as compared with environmental factors (including nutritional factors) on autoantibody expression. Cow's milk was identified as the source of the antigen, and the gastrointestinal tract as the route of exposure, in cerebral folate deficiency syndrome. ${ }^{6} \mathrm{~A}$ recent cross-sectional study ${ }^{3}$ reported that the midgestation autoantibody titer was higher, by $35 \%$, among women carrying a fetus affected by a neural-tube defect than among pregnant controls; however, differences in their analytical approach make it difficult to compare that report with our study.

Da Costa and Rothenberg were, to our knowledge, the first to report the presence of elevated folate-binding proteins in serum from women using oral contraceptives or during pregnancy. ${ }^{13} \mathrm{Al}-$ though the exact function of folate receptors is not well understood, ${ }^{14}$ recent work suggests that these receptors are highly antigenic. It is possible that conditions associated with an increased expression of folate receptors ${ }^{15}$ can evoke an autoantibody response in susceptible persons. Autoantibodies in blood may reflect excess free antibody, with most of the autoantibodies bound to receptors expressed on tissue cells. Folate-receptor autoantibodies seem to be common in patients with breast or ovarian cancer. ${ }^{16}$ Their significance is unknown, although in vitro studies suggest that autoantibodies blocking the folic acid-binding site could interfere with folate uptake. ${ }^{2}$ It remains possible that the presence of an increased titer of these autoantibodies in a woman's blood in early pregnancy may exacerbate the effect of low folate levels and further deprive the developing embryo, thereby influencing the final outcome with regard to a neural-tube defect.

In summary, in contrast to findings in a smaller pilot study, we found no significant association between the presence of folate-receptor autoantibodies and a history of pregnancy complicated by a neural-tube defect in two studies in an Irish population. We also found no association between antibody titers and a history of pregnancy affected by a neural-tube defect. Further study is needed to better understand the prevalence among various populations, and the pathological relevance, of folate-receptor autoantibodies.

Supported by the intramural research programs of the Eunice Kennedy Shriver National Institute of Child Health and Human Development (N01-HD-3-3348) and the Health Research Board, Ireland, and a grant from the National Institutes of Health (HD051880, to Dr. Quadros).

Drs. Quadros and Sequeira report serving as consultants for IMMCO Diagnostics and having filed a patent application for a kit for the determination of folate-receptor autoantibodies. No other potential conflict of interest relevant to the article was reported.

We thank the affected families for their participation and the Irish Association for Spina Bifida and Hydrocephalus.

\section{REFERENCES}

1. Tamura T, Picciano MF. Folate and human reproduction. Am J Clin Nutr 2006; 83:993-1016.

2. Rothenberg SP, da Costa MP, Sequeira JM, et al. Autoantibodies against folate receptors in women with a pregnancy complicated by a neural-tube defect. N Engl J Med 2004;350:134-42.

3. Cabrera RM, Shaw GM, Ballard JL, et al. Autoantibodies to folate receptor during pregnancy and neural tube defect risk. J Reprod Immunol 2008;79:85-92.

4. Ramaekers VT, Rothenberg SP, Sequeira JM, et al. Autoantibodies to folate receptors in the cerebral folate deficiency syndrome. N Engl J Med 2005;352:198591.

5. Ramaekers VT, Blau N, Sequeira JM, Nassogne MC, Quadros EV. Folate recep- tor autoimmunity and cerebral folate deficiency in low-functioning autism with neurological deficits. Neuropediatrics 2007; 38:276-81.

6. Ramaekers VT, Sequeira JM, Blau N, Quadros EV. A milk-free diet downregulates folate receptor autoimmunity in cerebral folate deficiency syndrome. Dev Med Child Neurol 2008;50:346-52.

7. Little J, Elwood JM. Geographical variation. In: Elwood JM, Little J, Elwood $\mathrm{JH}$, eds. Epidemiology and control of neural tube defects. Monographs in epidemiology and biostatistics. Vol. 20. Oxford, England: Oxford University Press, 1992: 96-145.

8. Shields DC, Kirke PN, Mills JL, et al. The "thermolabile" variant of methylenetetrahydrofolate reductase and neural tube defects: an evaluation of genetic risk and the relative importance of the genotypes of the embryo and the mother. Am J Hum Genet 1999;64:1045-55.

9. Brody LC, Conley M, Cox C, et al. A polymorphism, R653Q, in the trifunctional enzyme methylenetetrahydrofolate dehydrogenase/methenyltetrahydrofolate cyclohydrolase/formyltetrahydrofolate synthetase is a maternal genetic risk factor for neural tube defects: report of the Birth Defects Research Group. Am J Hum Genet 2002;71:1207-15.

10. Molloy AM, Scott JM. Microbiological assay for serum, plasma, and red cell folate using cryopreserved, microtiter plate method. Methods Enzymol 1997;281:43-53. 11. Bliek JB, Rothenberg SP, SteegersTheunissen RP. Maternal folate receptor 
autoantibodies and cleft lip and/or palate. Int J Gynaecol Obstet 2006;93:142-3.

12. Berrocal-Zaragoza MI, FernandezBallart JD, Murphy MM, Cavallé-Busquets P, Sequeira JM, Quadros EV. Association between blocking folate receptor autoantibodies and subfertility. Fertil Steril 2009;91:Suppl:1518-21.

13. Da Costa M, Rothenberg SP. Appearance of a folate binder in leukocytes and serum of women who are pregnant or taking oral contraceptives. J Lab Clin Med 1974;83:207-14.

14. Kelemen LE. The role of folate receptor alpha in cancer development, progression and treatment: cause, consequence or innocent bystander? Int J Cancer 2006; 119:243-50.

15. Elnakat H, Ratnam M. Distribution, functionality and gene regulation of fo- late receptor isoforms: implications in targeted therapy. Adv Drug Deliv Rev 2004; 56:1067-84.

16. Knutson KL, Krco CJ, Erskine CL, et al. T-cell immunity to the folate receptor alpha is prevalent in women with breast or ovarian cancer. J Clin Oncol 2006;24: 4254-61.

Copyright (๑) 2009 Massachusetts Medical Society. 